\title{
IMPACT OF BUILDING ENVELOPE DESIGN ON ENERGY CONSUMPTION OF LIGHT STRUCTURE SCHOOL BUILDING
}

\author{
BIN SU \\ Department of Architecture, Unitec Institute of Technology, Auckland, New Zealand
}

\begin{abstract}
According to the local climate, an Auckland school building normally does not need air conditioning for cooling during the summer and only needs space heating during the winter. Previous study shows that the mean winter energy consumption is about $38 \%$ of the mean annual energy consumption of Auckland school buildings. The mean winter extra energy, which mainly includes space heating, water heating and other appliances related to winter indoor thermal conditions, is about $44 \%$ of winter energy consumptions. Extra winter energy of a school building is closely related to and impacted by building thermal design and thermal performance. Although different building design factors related to the main architectural feature, building elements and materials can affect the school energy consumption differently and simultaneously, the relationship between building design data and school energy consumption data can still be identified. With a larger number of sample school buildings, this study focuses on impact strength of building design factors on school winter extra energy consumptions and identifies quantitative relationships between the building design data and the winter extra energy consumption data, which can be used to proximately estimate the amount of saving winter extra energy consumption associated with the change of a design datum for the future school development. In Auckland, there are 425 schools including primary, intermediate and high schools. Real energy consumption and building design data of 57 local schools (13.4\% of the total number of Auckland schools) are randomly selected for this study.
\end{abstract}

Keywords: Building elements, Building energy, Building energy efficiency, Building envelope design, Building thermal design, School building.

\section{INTRODUCTION}

The World Health Organisation recommends a minimum indoor temperature for houses of $18^{\circ} \mathrm{C}$; and $20-21^{\circ} \mathrm{C}$ for more vulnerable occupants, such as older people and young children (WHO 1987). Current New Zealand Building Codes do not have a general requirement for the minimum indoor air temperature, although it has a requirement of $16^{\circ} \mathrm{C}$ for more vulnerable occupants, such as older people and young children (SANZ 1990, DBH 2001). There are a number of previous studies on the impact of different building design factors on energy efficiency. These design factors are mainly related to building orientation, geometry and envelope. Some studies focus on building orientation, which is one of most important design factors for building energy efficiency, impacting on solar radiation received (Gupta 2004, Morrissey 2011) and shading (Capeluto 2003). Other studies focus on the impact of building shape (Marks 
1997, Florides et al. 2002, Mingfang 2002, Adamski 2007) with different orientations (Marks 1997, Florides et al. 2002, Aksoy 2006, Adamski 2007); or on energy consumptions under different climates (Depecter et al. 2001). All heat exchanges between indoor space and outdoor space are through the building envelope, which has the greatest impact on building energy consumption (Manioglu et al. 2006, Radhi 2008]. Those studies mainly based on mathematical models and computer simulations. It is difficult to establish universal building passive design guides to achieve energy efficiency for different local buildings and climates. This study uses the difference between mean daily energy usage in the winter months (the likely heating months: June, July and August) and the other months of the year (unlikely heating months) to roughly represent the extra winter energy consumption, which mainly comprises space heating and extra energy for hot water heating, and can also include extra energy for appliances, which are impacted by the winter internal thermal conditions of a school. Smaller extra winter energy usage indicates better indoor thermal conditions and building thermal performance in response to the winter climatic conditions. Actual monthly energy consumption data for a whole year, which can be converted into daily energy usage per unit volume of indoor space $\left(\mathrm{kWh} / \mathrm{m}^{3} /\right.$ day $)$, and building design data derived from real building plans supplied by the Auckland Council of 57 Auckland sample schools are used for this study. This study uses the gradient of the trend line to evaluate the impact strength of a design datum on winter extra energy consumption per cubic meter of indoor space of school building $\left(\mathrm{kWh} / \mathrm{m}^{3} /\right.$ day $)$, and estimate the decrease of winter extra energy consumption when a design datum is changed within a range when other design data also impact the winter extra energy consumption differently and simultaneously for future school development. Table 1 and Table 2 show general information and energy data of the sample school and buildings.

Table 1. General information of sample schools

\begin{tabular}{lcc}
\hline General information & Mean & Range \\
\hline Number of students & 626 & $109-2600$ \\
Number of isolated buildings & 9.4 & $1-38$ \\
Building height (stories) & 1.4 & $1-3$ \\
Number of classrooms & 30.5 & $5-135$ \\
Student number per classroom & 22 & $12-33$ \\
School floor area $\left(\mathrm{m}^{2}\right)$ & 5257 & $905-22680$ \\
Classroom / building floor area & $48 \%$ & $19 \%-80 \%$ \\
Floor area per classroom & $77 \mathrm{~m}^{2}$ & $51-141 \mathrm{~m}^{2}$ \\
\hline
\end{tabular}

Table 2. Energy consumption data of sample school buildings

\begin{tabular}{lcc}
\hline Energy(kWh) & Mean & Range \\
\hline Annual & 242633 & $16376-1498621$ \\
Winter & 92951 & $5662-570679$ \\
Winter/annual & $38 \%$ & $29 \%-49 \%$ \\
Summer & 33199 & $2783-164123$ \\
Winter/summer & 2.8 & $2.0-3.5$ \\
Summer/annual & $14 \%$ & $7 \%-20 \%$ \\
Heating months & 144892 & $8699-900417$ \\
Heating months/annual & $58 \%$ & $48 \%-76 \%$ \\
\hline
\end{tabular}




\section{BUILDING DESIGN FACTORS}

\subsection{Ratio of Building Surface to Volume}

The ratios of building surface to volume of the sample school buildings are 0.31 to 0.74 with a mean ratio of 0.48 . Conventional school design in Auckland, with many lowrise isolated buildings spread over a large site area is not energy efficient under the local climate. Over $90 \%$ of Auckland schools only have four or less classrooms in each isolated school building (see Figure 1). An increase in the ratios of building surface to volume of the sample schools is associated with an upward trend in winter extra energy consumption (see Figure 2). A school building with a high ratio of building surface to volume has a large external surface area, which results more heat-loss and more energy consumption for space heating and other appliances during the winter. Based on the gradient $(0.023)$ of the trend line in Figure 2, the mean winter extra energy $\left(0.0234 \mathrm{kWh} / \mathrm{m}^{3} / \mathrm{day}\right)$ and mean ratio of building surface to volume of the sample schools, Eq. (1) can be used to proximately estimate the amount of increasing or decreasing mean winter extra energy consumption $\left(\Delta \mathrm{E}_{\mathrm{WE}}\right)$ associated with the decrease or the increasing of the mean ratio of building surface to volume $\left(\Delta \mathrm{R}_{\mathrm{SV}}\right)$ of the future school development under the local climate, for example, decreasing the mean ratio from 0.48 to 0.28 , input data into the Eq. (1): $0.0234-\mathrm{E}_{\text {future }}=0.023 \times(0.48-0.28)$, the future mean winter extra energy consumption $\mathrm{E}_{\text {future }}=0.0234-0.023 \times(0.48-0.28)=$ $0.0234-0.0046=0.0188 \mathrm{kWh} / \mathrm{m}^{3} /$ day, and Table 3 shows that relationships between reduction (from $3.9 \%$ to $19.7 \%$ ) of mean winter extra energy related to decrease (from 0.48 to 0.32 ) of mean ratio of building surface to volume for future Auckland school development.

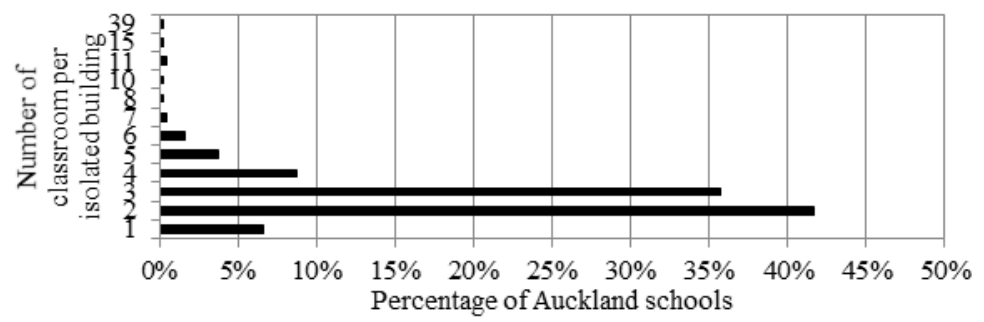

Figure 1. Number of classrooms per school building in Auckland

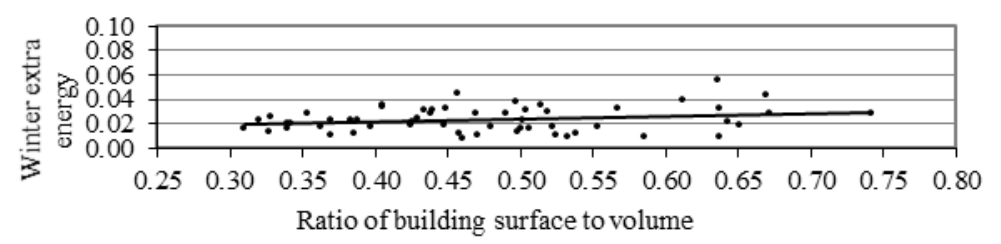

Figure 2. Winter extra energy and ratios of building surface to volume of sample schools

$$
\Delta \mathrm{E}_{\mathrm{WE}}=0.023 \Delta \mathrm{R}_{\mathrm{SV}}
$$


Table 3. Reduction of mean winter extra energy $\left(\mathrm{kWh} / \mathrm{m}^{3}\right.$ day $)$ associated with decrease of mean ratio of building surface to volume of future school building development

\begin{tabular}{cccc}
\hline $\begin{array}{c}\text { Ratios of building } \\
\text { surface to volume }\end{array}$ & $\begin{array}{c}\text { Decrease of mean } \\
\text { winter extra energy }\end{array}$ & $\begin{array}{c}\text { Mean winter extra } \\
\text { energy }\end{array}$ & $\begin{array}{c}\text { Energy } \\
\text { saving }\end{array}$ \\
\hline 0.44 & $0.00092 \mathrm{kWh} / \mathrm{m}^{3}$ day & $0.02248 \mathrm{kWh} / \mathrm{m}^{3}$ day & $3.9 \%$ \\
0.40 & $0.00184 \mathrm{kWh} / \mathrm{m}^{3}$ day & $0.02156 \mathrm{kWh} / \mathrm{m}^{3}$ day & $7.9 \%$ \\
0.36 & $0.00276 \mathrm{kWh} / \mathrm{m}^{3}$ day & $0.02064 \mathrm{kWh} / \mathrm{m}^{3}$ day & $11.8 \%$ \\
0.32 & $0.00368 \mathrm{kWh} / \mathrm{m}^{3}$ day & $0.01972 \mathrm{kWh} / \mathrm{m}^{3}$ day & $15.7 \%$ \\
0.28 & $0.00460 \mathrm{kWh} / \mathrm{m}^{3}$ day & $0.01880 \mathrm{kWh} / \mathrm{m}^{3}$ day & $19.7 \%$ \\
\hline
\end{tabular}

\subsection{Ratios of Roof Surface Area and Wall Surface Area to Building Volume}

The ratios of roof surface area to building volume of the sample school buildings are 0.12 to 0.42 with a mean ratio of 0.26 and the ratios of wall surface area to building volume are 0.40 to 0.09 with a mean ratio of 0.22 . An increase in the ratios of roof surface area to building volume or the ratios of wall surface area to building volume is associated with an upward trend in winter extra energy consumption (see Figure 3, 4). The gradient of the trend line of roof (0.0426) is higher than wall (0.0141). A low rise building such as a house with 1 to 2 stories loses more heat through roof than wall. Auckland houses with 1 to 2 stories loses about $40 \%$ of its heat through ceiling and roof and about $20 \%$ of its heat through wall during the winter. The ratios of roof surface area to building volume of Auckland houses are 0.12 to 0.40 with a mean ratio of 0.29 [Su 2011]. The ratios of roof surface area to building volume of the sample school buildings are very close to the local houses. Roof of Auckland school buildings should be a more important building element or portion of building envelope than the walls for the local school buildings. Decreasing mean ratio of roof surface area to building volume can cause a more positive impact on winter extra energy of Auckland school buildings than the mean ratio of wall surface area to building volume. Eq. (2) and Eq. (3) can be used to proximately estimate the amount of increasing or decreasing mean winter extra energy consumption $\left(\Delta \mathrm{E}_{\mathrm{WE}}\right)$ associated with the increasing or the decrease of the mean ratio of roof surface to building volume $\left(\Delta R_{R V}\right)$ and the mean ratio of wall surface to building volume $\left(\Delta \mathrm{R}_{\mathrm{WV}}\right)$ of the future school development under the local climate.

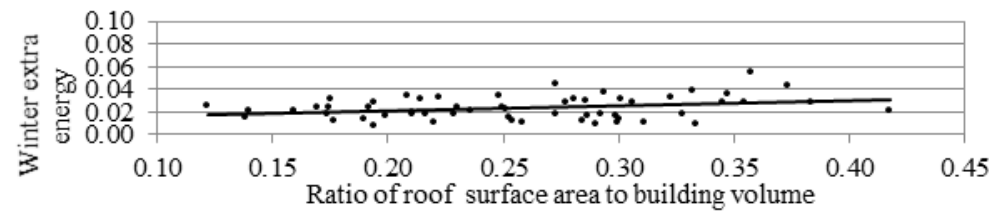

Figure 3. Winter extra energy and ratio of building roof surface area to building volume

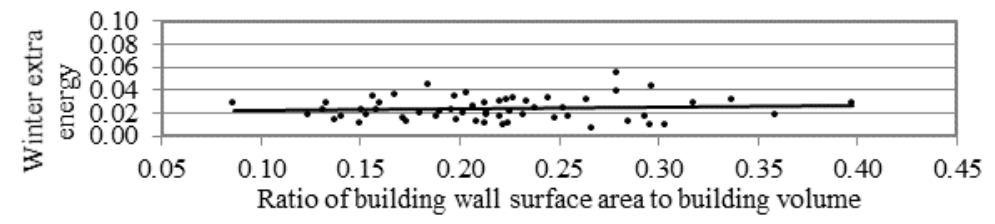

Figure 4. Winter extra energy and ratio of building wall surface area to building volume 


$$
\begin{aligned}
& \Delta \mathrm{E}_{\mathrm{WE}}=0.0426 \Delta \mathrm{R}_{\mathrm{RV}} \\
& \Delta \mathrm{E}_{\mathrm{WE}}=0.0141 \Delta \mathrm{R}_{\mathrm{WV}}
\end{aligned}
$$

\subsection{Ratio of Roof Space Volume to Building Volume}

The ratios of roof space volume to building volume of the sample school buildings are 0.02 to 0.36 with a mean ratio of 0.13 . An increase in the ratios of roof space volume to building volume is associated with a downward trend in winter extra energy consumptions of the sample school buildings (see Figure 5). Increasing roof space volume can positively impact on saving winter extra energy consumption for the low rise school buildings. A roof space can be buffering space for heat-loss during the winter and increase R-value of roof. Eq. (4) can be used to proximately estimate the amount of increasing or decreasing mean winter extra energy consumption $\left(\Delta \mathrm{E}_{\mathrm{WE}}\right)$ associated with the decrease or the increasing of the mean ratio of roof space volume to building volume $\left(\Delta \mathrm{R}_{\mathrm{RSV}}\right)$ of the future school development under the local climate.

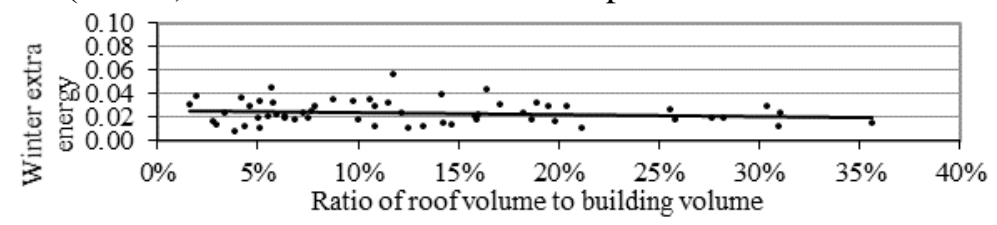

Figure 5. Winter extra energy and ratio of roof volume to building volume

$$
\Delta \mathrm{E}_{\mathrm{WE}}=0.0171 \Delta \mathrm{R}_{\mathrm{RSV}}
$$

\subsection{Ratio of Window Area to Building Volume}

The ratios of window to building volume of the sample school buildings are in the ranges of 0.02 to 0.1 with a mean ratio of 0.05 . An increase in the ratios of window area to building volume is also associated with an upward trend in winter extra energy consumption (See Figure 6). The gradient of the trend line of the ratio of window area to building volume is 0.0762 , which is much higher than roof $(0.0426)$ and wall (0.0141). Window area are generally weak part of building envelope with low R-value for building thermal design. Even using double glazed windows, the R-value $(0.26$ $\left.\mathrm{m}^{2 \circ} \mathrm{C} / \mathrm{W}\right)$ is still very low compared with wall $\left(1.5-1.9 \mathrm{~m}^{2 \circ} \mathrm{C} / \mathrm{W}\right)$ or roof $(1.9-2.9$ $\mathrm{m}^{2 \circ} \mathrm{C} / \mathrm{W}$ ), and increasing the ratio of window area to building volume can still cause stronger negative impact on winter extra energy than increasing the ratios of roof and wall to building volume. Eq. (5) can be used to proximately estimate the amount of increasing or decreasing mean winter extra energy consumption $\left(\Delta \mathrm{E}_{\mathrm{WE}}\right)$ associated with the increasing or the decrease of the mean ratio of window area to building volume $\left(\Delta \mathrm{R}_{\mathrm{WV}}\right)$.

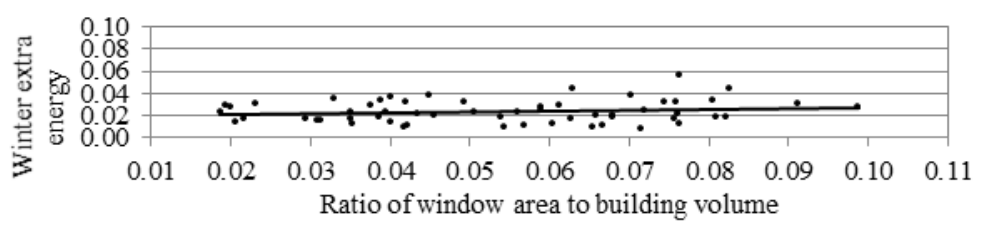

Figure 6. Winter extra energy and ratio of window area to building volume

$$
\Delta \mathrm{E}_{\mathrm{WE}}=0.0762 \Delta \mathrm{R}_{\mathrm{WV}}
$$




\section{CONCLUSIONS}

From the energy efficiency point of view, Auckland school conventional design with a high ratio of building surface to volume is not good for energy efficiency. Changing school building design conventions from low rise to multi-stories building not only can reduce ratio of building surface to volume but also reduce winter extra energy. Based on energy consumption and design data of the 57 Auckland sample schools, reducing mean ratio of building surface to volume from 0.48 to 0.28 can potentially reduce about $20 \%$ of winter extra energy consumption for the future school building development. There are thousands of old classrooms need to be retrofitted for improving their thermal performance and energy efficiency in New Zealand. According to envelope design data for the sample school buildings, the window area is the weakest portion of the envelope, having the lowest R-value, and more negative impact on winter extra energy than roof and wall. The first thing to do for retrofitting an old school building is to improve the thermal performance of the window area to reduce heat loss; and secondly, the roof area, which has more negative impact on winter extra energy than the wall area.

\section{References}

Adamski, M., Optimization of the form of a building on an oval base, Building and Environment, 42(4), 1632-1643, 2007.

Aksoy, U. T., and Inalli, M., Impacts of some building passive design parameters on heating demand for a cold region, Building and Environment, 41(12), 1742-1754, December, 2006.

Capeluto, I. G., Energy performance of the self-shading building envelope, Energy and Buildings, 35(3), 327-336, 2003.WHO, Health Impact of Low Indoor Temperatures, World Health Organization, Copenhagen, Denmark, 1987.

DBH, Compliance Document for New Zealand Building Code - Clause G5 Interior Environment, Department of Building and Housing, Wellington, New Zealand, 2001.

Depecter, P., Menezo, C., Virgone, J., and Lepers, S., Design of building shape and energetic consumption, Building and Environment, 36(5), 627-635, June 2001.

Florides, G. A., Tassou, S. A., Kalogirou, S. A., and Wrobel, L. C., Measures used to lower building energy consumption and their cost effectiveness, Applied Energy, 73(3-4), 299-328, November-December, 2002.

Gupta, R., and Ralegaonkar, R. B., Estimation of beam radiation for optimal orientation and shape decision of buildings in India, Architectural Journal of Institution of Engineers India, 85, 27-32, 2004.

Manioglu, G., and Yilmaz, Z., Economic evaluation of the building envelope and operation period of heating system in terms of thermal comfort, Energy and Buildings, 38 (3), 266-272, 2006.

Marks, W., Multicriteria optimisation of shape of energy-saving buildings, Building and Environment, 32(4), 331-339, 1997.

Mingfang, T., Solar control for buildings, Building and Environment, 37(7), 659-664, 2002.

Morrissey, J., Moore, T., and Horne, R.E., Affordable passive solar design in a temperate climate: an experiment in residential building orientation, Renewable Energy, 36(2), 568-577, 2011.

Radhi, H., A systematic methodology for optimising the energy performance of buildings in Bahrain, Energy and Buildings, 40(7), 1297-1303, 2008.

SANZ, New Zealand Standard 4303-1990 Ventilation for acceptable indoor air quality, Standards Association of New Zealand, Wellington, New Zealand, 1990.

$\mathrm{Su}$, B., The impact strength of building passive design on housing energy efficiency, Architectural Science Review, 54(4), 270-276, 2011. 